\title{
Operation Allelopathy: An Experiment Investigating an Alternative to Synthetic Agrochemicals
}

\author{
Nuria Chinchilla, ${ }^{\dagger}$ Alexandra G. Durán, ${ }^{\dagger}$ Ceferino Carrera, ${ }^{\dagger}$ Jesús Ayuso, $^{\ddagger}$ and Francisco A. Macías ${ }^{*},^{\dagger}$ \\ Grupo de Alelopatía de Cádiz, `Departamento de Química Organica and ${ }^{\ddagger}$ Departamento de Química Física, Universidad de Cádiz, \\ Campus de Excelencia Internacional Agroalimentario (ceiA3), Avenida República Saharaui, 11510 Puerto Real, Cádiz, Spain
}

\section{Supporting Information}

\begin{abstract}
Synthetic herbicides represent a serious problem in modern agriculture because they are not biodegradable and can accumulate in the soil and in the groundwater, a situation that allows them to enter the trophic chain and ultimately leads to human exposure. Allelopathic chemicals offer an effective alternative to the synthetic compounds. The aim of this experiment is to highlight the differences between chemical and biological control of diseases in crops and to demonstrate the use of natural fungicides and herbicides as alternatives to synthetic chemicals. The experiment involves an evaluation by students of the potential of plant extracts as an alternative to synthetic agrochemicals to identify new ecological farming techniques that could be applied in agriculture. In an effort to encourage 1800 students in high school (14 to 16 years old) to have an interest in science, technology, and innovation, the third edition of the Summer Science Campus was organized by the Spanish Foundation for Science and Technology and the Ministry of Education, Culture, and Sports with support from the foundation Obra Social "la Caixa".
\end{abstract}

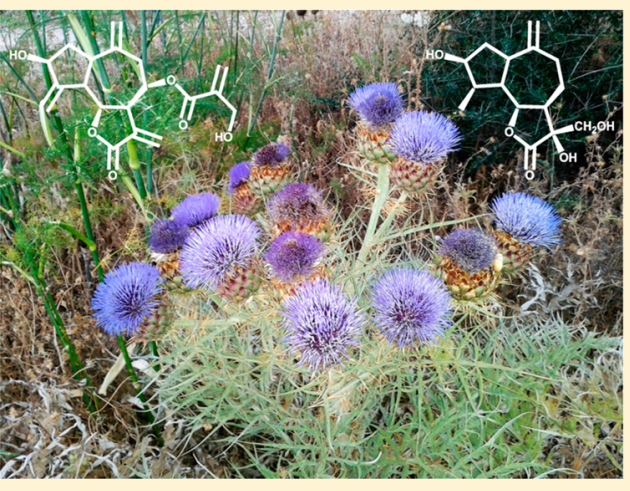

KEYWORDS: High School/Introductory Chemistry, Environmental Chemistry, Laboratory Instruction,

Hands-On Learning/Manipulatives, Agricultural Chemistry, Bioanalytical Chemistry, Natural Products, Plant Chemistry

\section{INTRODUCTION}

\section{Weed Control}

Since the beginning of agriculture, weed control has been essential to ensure the survival of crops. A weed is understood to be "any plant growing in a place and at a time unwanted" and, for this reason, they are often also called "unwelcome plants". Currently, control of weeds is mainly achieved by using synthetic herbicides, but their continued use has led to the emergence worldwide of resistant biotypes. ${ }^{1,2}$ The excessive use of herbicides is causing a serious environmental pollution problems. ${ }^{3,4}$ These substances, which in many cases are not biodegradable, have a high persistence level in the soil and are accumulated in groundwater. Instead, natural products constitute an attractive source of agrochemicals with great potential. They are biodegradable, have a broad structural diversity, present new modes of action as well as are active at low doses and are selective. ${ }^{5-7}$

\section{Allelopathy}

An alternative current proposal for the control of weeds, not only for resistant species, is so-called biological control. This involves the use of the strategies employed by plants in nature to fend off attackers and competitors. ${ }^{8,9}$ Allelopathy (Greek allelon = each other, pathos = suffering; mutual interaction) is the science that concerns any process involving plant or microbial metabolites, preferably secondary, that influence the growth and development of biological systems. ${ }^{10}$ Extensive literature on plants with allelopathic activity is available, especially for crops of great interest such as wheat, ${ }^{11}$ sunflower, ${ }^{12,13}$ or rye, ${ }^{14}$ among others.

\section{Chemistry of Plants}

Students are familiar with plants ${ }^{15}$ and chemistry, but do they know about the chemistry of plants? ${ }^{16}$ Over millions of years plants have had to defend themselves from attacks by phytophages and microorganisms as well as other plants competing for soil nutrients, light, humidity, and so forth. Thus, plants have developed a number of morphological and chemical defense mechanisms to ensure their survival. Allelochemicals are found within these compounds of defense, which are found in the tissues of plants, and can be released to the environment through four pathways: volatilization, lixiviation, decomposition, or exudation. Thereby, the plants provide a valuable source of bioactive compounds with unexploited properties and new structures. ${ }^{17}$

\section{BACKGROUND OF THE EXPERIMENT}

The first contact that students have with experimental science institutes generally does not enable them to gain an idea of the variety of applications that science has in this setting. For this reason the Spanish Foundation for Science and Technology (FECYT) has launched an outreach program for young science

Published: November 22, 2013 
Sylibum marianum<smiles>COc1ccc(C2Oc3ccc([C@@H]4Oc5cc(O)cc(O)c5C(=O)C(O)[C@H]4C)cc3O[C@@H]2CO)cc1O</smiles><smiles></smiles>

Silybin B

Onopordum acanthium<smiles>COc1ccc(CC(CO)C(Cc2ccc(O[C@@H]3O[C@H](CO)[C@@H](O)[C@H](O)[C@H]3O)c(OC)c2)C(=O)O)cc1OC</smiles>

Aconiside<smiles>CC(C)(C)O</smiles>

Cynara cardunculus \& scolymus<smiles>C=C1CC[C@H]2[C@@H](OC(=O)[C@@]2(C)CO)[C@H]2C1C[C@H](O)[C@@H]2C</smiles>

Cynaratriol<smiles>C=C(CO)C(=O)O[C@H]1CC(=C)C2CC(O)C(=C)C2[C@@H]2OC(=O)C(=C)C12</smiles>

Cynaropicrin

Figure 1. Chemicals components of selected thistles.

researchers. ${ }^{18}$ The main objective of the program is to bring science, technology, and innovation to students. They can appreciate firsthand how researchers and teachers work, and the program encourages students to consider scientific vocations, thereby promoting the future of scientific and technical degrees. The Allelopathy Research Group of Cádiz (GAC) organized and conducted the workshop on "Sustainable Agriculture". Given the experience of the host research group in allelopathy in higher plants and microorganisms, ${ }^{19}$ an experiment was proposed that would allow students to understand the concept of biological control and sustainable agriculture. ${ }^{20}$ In total, 28 students from Scientific Campus Summer 2012 participated in this workshop during the month of July 2012 (7 students per week). The theme of the workshop was to show participants the differences between chemical control and biological control of diseases in crops and to enable them to use natural fungicides and herbicides as alternatives to synthetic chemicals. $^{21,22}$ The participants gained insight into the importance of using biodegradable substances in agriculture and learned about bioactive molecules, obtained either by isolation or synthesis techniques, based on natural products. ${ }^{23}$

\section{EXPERIMENTAL OVERVIEW}

\section{Preliminary (Coleoptiles Bioassay) and Herbicide} (Greenhouse Bioassay) Assessments

In the workshop, extracts from five plants that have traditionally shown allelopathic effects were prepared. The aqueous extracts of each species were obtained using different extraction conditions. The effects of these extracts on the growth of plants were analyzed using the following protocol. First, the preliminary activity of the extracts was assayed using wheat apical meristems in the coleoptiles bioassay. ${ }^{24}$ This is a quick and simple method to indicate the range of activity of the tested extract set and to assess the effect on cell growth. Second, the ability of each natural extract as an herbicide was investigated on the growth of seeds from three types of weeds that affect major crops worldwide. This investigation was carried out by the students in the greenhouse of the University of Cádiz. Finally, the results obtained in the first and the second bioassays were compared for each group. ${ }^{25}$

Types of Thistles and Chemistry

There are many plants that have shown allelopathic activity and that have been widely studied, such as sunflower, wheat, corn, ${ }^{26}$ or walnut tree, one of the trees with allelopathic activity better known. $^{27,28}$ For this experience, thistles from five different species were chosen: Silybum marianum, Onopordum acanthium, Cynara scolymus, Scolymus hispanicus, and Cynara cardunculus. These species belong to the Compositae family and were selected due to the activity described in the literature for their active principles. ${ }^{29,30}$

Sylibum marianum commonly known as "milk thistle" is one of the oldest and thoroughly researched plants against hepatotoxicity. One of the main phytoconstituents is flavolignan silybin, which has shown several pharmacological activities such as hepatoprotective, anti-inflammatory, antioxidant, and antiviral activities, in addition to allelopathic effects on seed germination of maize. ${ }^{31,32}$ 
Moreover, artichokes (Cynara scolymus and Cynara cardunculus) are well-known for their nutritional and curative properties against several diseases. ${ }^{33,34}$ Two bitter sesquiterpene lactones obtained from genus Cynara are cynaratriol and cynaropicrin, both of them have shown a wide range of activities, including antifeedant role as defense mechanism against predators.

Polyphenols and inulin are found among the active compounds of Scolymus hispanicus (with antioxidant properties). ${ }^{35}$ Inulin is a complex carbohydrate with fructose chains found in some plants as a reserve substance. Among its many therapeutic uses, it is noteworthy to note its use as a probiotic and promoting absorption of calcium. ${ }^{36}$ Onopordum acanthium contains alkaloids, flavone glycosides, ${ }^{37}$ aesculin (a very toxic saponin to humans and animals), tannins, and other bitter chemicals. Some chemicals components of selected thistles are shown in the Figure 1.

\section{EXPERIMENTAL DETAILS}

\section{Logistics}

The workshop was carried out by four groups of seven students spread over four different weeks. The experiment was divided into three parts: preparation of plant extracts, the assay on cell growth, and the assay on weeds in greenhouse crops.

\section{Part I: Extraction}

In the first part, each group of students prepared extracts from the five species using water as the extraction medium to emulate natural conditions and also to avoid the risk involved in using organic solvents. Each group used different extraction conditions (see Table 1; details are in the Supporting

\section{Table 1. Extraction Conditions Used by Each Group}

$\begin{array}{ccclcc}\text { Group } & \begin{array}{c}\text { Plant Dry } \\ \text { Weight/g }\end{array} & \begin{array}{c}\text { Water } \\ \text { Volume/ } \\ \mathrm{mL}\end{array} & \text { Conditions } & \text { Time } & \begin{array}{c}\text { Selected } \\ \text { Extracts }\end{array} \\ \text { I } & 50 & 450 & \text { Maceration } & 24 \mathrm{~h} & \begin{array}{c}\text { Onopordum } \\ \text { acanthium }\end{array} \\ \text { III } & 50 & 450 & \text { Ultrasound }^{a} & 25 \mathrm{~min} & \begin{array}{c}\text { Scolymus } \\ \text { hispanicus } \\ \text { IV }\end{array} \\ \text { IV } & 50 & 450 & \text { Ultrasound }^{b} & 25 \mathrm{~min} & \begin{array}{c}\text { Onopdum } \\ \text { acanthium } \\ \text { Cynara } \\ \text { cardunculus }\end{array}\end{array}$

${ }^{a}$ Output amplitude $100 \%$ duty cycle $0.5 .{ }^{b}$ Output amplitude $100 \%$ duty cycle 1.0 .

Information). The resulting extracts were filtered and subsequently 1:5 and 1:10 dilutions were prepared, in addition to the undiluted sample $(1: 1)$, for the following steps. Thus, three different concentrations were tested from each species and therefore the activity and the concentration effects could be evaluated. The first level of assay was the coleoptiles bioassay, which is also known as the general activity bioassay. This bioassay carried out on undifferentiated cells of plant tissue, where cell elongation is measured at $24 \mathrm{~h}$.

In this part, students used basic techniques that are common in laboratory work: vacuum filtration, gravity filtration, use of volumetric glassware and pipets, and so forth.

\section{Part II: Assay on Cell Growth}

In the second part, each group of students screened the plant extracts to assess the best candidate for allelopathic activity. This screening involved a general activity bioassay (coleoptiles bioassay) ${ }^{24}$ which allowed the rapid identification $(24 \mathrm{~h})$ of the extract(s) that had an effect on cell growth. A total of five plant extracts were used at three different concentrations with three replicates for each concentration. The coleoptiles were measured by applying digital photography (Photomed). Data were statistically analyzed using Welch's test. ${ }^{38}$ Each group of students selected the species that showed the highest activity according to its extraction method. The results were represented graphically in a way that shows the activity of each of the extracts versus the control (weed growth without extract added). Also, in each experiment, the extract that showed a more regular activity profile was selected, that is, the extract in which activity was maintained at lower concentrations. In this bioassay, students used statistical concepts applied to science to interpret results and to draw conclusions.

\section{Part III: Assay on Weeds in Greenhouse Crops}

In the third part, the assessment of the activity of selected extracts as potential natural herbicides was carried out in a series of experiments conducted in the research greenhouse. The assays on the growth of weeds were performed by controlling different factors: light, humidity, temperature, and irrigation system.

The weeds used in the different experiments are common in commercial crops: Avena fatua, Lolium rigidum, and Echinochloa crus-galli. These weeds are harmful to crops of global importance such as rice, corn, and wheat. The test was carried out on weed seedlings planted previously by the students in hydroponic systems. The activity under investigation can be assessed in numerous different ways, including quantification of the chlorophyll content of seedlings or measurement of the fresh weight, among others. In these experiments, the activity was evaluated by weighing the seedlings and comparing them with a control. The results were examined graphically by plotting the activity of each weed.

\section{HAZARDS}

Students worked with aqueous solutions and wore lab coats, protective gloves, and eye protection, as prescribed in the health and safety protocol. Advice was provided and special attention was paid when students worked with cutting material and glassware. Waste was disposed of according to the guidelines for laboratory hazardous waste management.

\section{RESULT AND DISCUSSION}

Each group of students carried out the assay on cell growth with the five extracts (data for each group is available in the Supporting Information) and selected the most active species based on their own criteria. A description of the conditions used in this test and the overall results are given in the Supporting Information. The activity data for the selected species measured by each group are shown in Figure 2. Results are presented as percentage differences from the control. Thus, zero represents the control, positive values represent stimulation of the studied parameter, and negative values represent inhibition. This means that if control coleoptiles growth is $4 \mathrm{~mm}$ and the treatment coleoptiles growth is $2 \mathrm{~mm}$, the products contained in the extracts caused 50\% growth inhibition. In contrast, if the coleoptiles with the treatment grow $6 \mathrm{~mm}$, the products caused 50\% growth stimulation.

Each group of students subsequently took the selected extract to the next level of bioassay, that is, hydroponics in the greenhouse. Each student group tested their choice of extract 


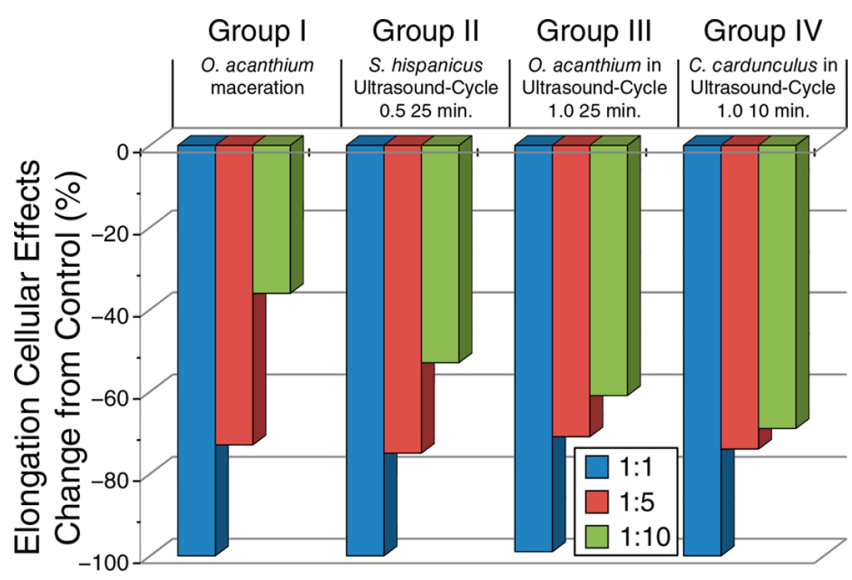

Figure 2. Cell growth inhibition showed by the best extract selected from each group of students.

on all three weeds. Prior to the assay, three weed seedlings were grown for 10 days with glass beads as the solid support and using Hoagland's salt as the nutrient. The extract was then added to the weed seedlings, and after 7 days the observed effect was evaluated. After growth, plants were collected and weighed to determine the fresh weight of plant material. Percentage of activity is given by the formula:

$$
\% \text { activity }=\frac{\text { fresh weight }_{\text {extract }}-\text { fresh weight }_{\text {control }}}{\text { fresh weight }_{\text {control }}} \times 100
$$

At this stage, the work of two consecutive groups overlapped. Thus, the cultivation of seedlings by one group was used by the following group to determine the herbicidal effect. Thus, each group evaluated the activity of the extract of the previous group. The results for the best extracts tested in the greenhouse from each group are represented in Figure 3 (all the student data are available in the Supporting Information).

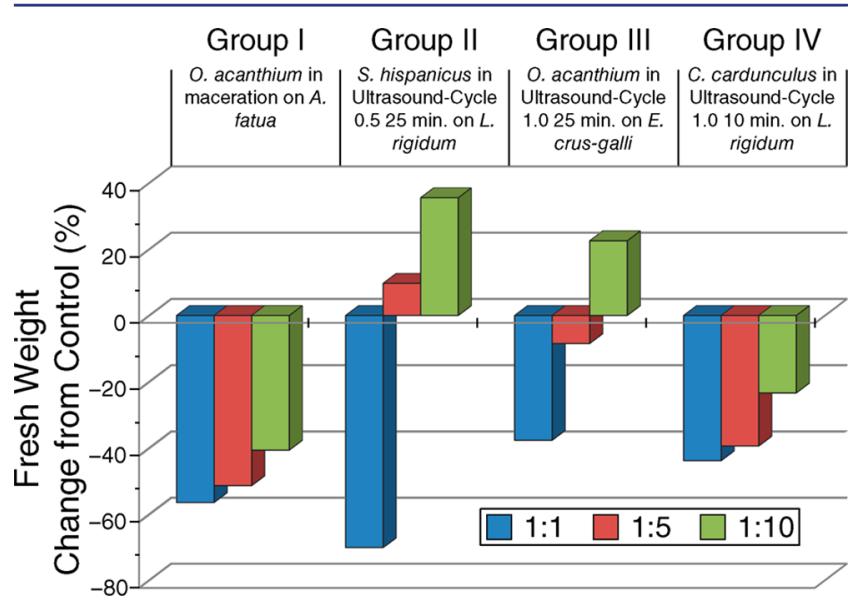

Figure 3. Growth weed inhibition showed in the greenhouse bioassay by the best-selected extracts.

\section{CONCLUSIONS}

Upon completion of the workshop, all participants had performed a screening of different plants from the region, evaluating their use as alternative herbicides to synthetic ones. The students also had the opportunity to recognize the macroscopic effects that the selected extract had on weeds.
These experiments enabled the students to gain an overview of each of the steps carried out for the development of natural product-based herbicides. Among other properties, it is expected that these natural product-based herbicides have more novel chemical structures, in this case, with guaianolide skeletons ${ }^{39}$ (since these are the most abundant on this plant species); show novel modes of action; ${ }^{40,41}$ are more compatible with the environment; and help to solve one of the main problems faced today, that is, herbicide resistance. Students became familiar with a research laboratory and the working methods used in this field and also gained an understanding of the costs of the materials and equipment required to perform this task with precision and rigor. In addition, the students learned to use techniques and instruments, to practice collaborative learning, and to make decisions throughout the process by reasoning. Even more importantly, the process was carried out within a friendly and stress-free atmosphere.

A summary of the student survey conducted by FECyT after the workshop is available in the Supporting Information. Over $90 \%$ of students stated that they would repeat the experience and over $80 \%$ said that it increased their interest in science.

\section{ASSOCIATED CONTENT}

\section{S Supporting Information}

Detailed procedures with comments and pictures, tables and figures of the biological activity results, and student survey results. This material is available via the Internet at http://pubs. acs.org.

\section{AUTHOR INFORMATION}

\section{Corresponding Author}

*E-mail: famacias@uca.es.

Notes

The authors declare no competing financial interest.

\section{ACKNOWLEDGMENTS}

This research was financially supported by the Spanish Foundation for Science and Technology and the Ministry of Education, Culture and Sports supported by the foundation Obra Social "la Caixa" and the Consejeria de Innovación, Ciencia y Empresa, Junta de Andalucía (Project P10AGR5822). Staff at the greenhouse serving the University of Cádiz are also gratefully acknowledged.

\section{REFERENCES}

(1) Preston, C. Herbicide Detoxification: Herbicide Selectivity in Crops and Herbicide Resistance in Weeds. In Environmental Fate and Safety Management of Agrochemicals; ACS Symposium Series, Vol. 899; Clark, J. M., Ohkawa, H., Eds.; American Chemical Society: Washington, DC, 2005; pp 195-204.

(2) Owen, M. D. K.; Zelaya, I. A. Herbicide-resistant crops and weed resistance to herbicides. Pest Manag. Sci. 2005, 61, 301-311.

(3) Sullivan, T. P.; Sullivan, D. S. Vegetation management and ecosystem disturbance: impact of glyphosate herbicide on plant and animal diversity in terrestrial systems. Environ. Rev. 2003, 11, 37-59.

(4) Wang, Y. S. Environmental impact of herbicide use in the subtropics. Food Sci. Agric. Chem. 1999, 1, 165-179.

(5) Dayan, E. F.; Owens, D. K.; Duke, S. O. Rationale for a natural products approach to herbicide discovery. Pest Manag. Sci. 2012, 68, 519-528.

(6) Battle, G. M.; Kyd, G. O.; Groom, C. R.; Allen, F.; Day, J.; Upson, T. Up the Garden Path: A Chemical Trail through the 
Cambridge University Botanic Garden. J. Chem. Educ. 2012, 89, 13901394.

(7) Rimando, A. M.; Duke, S. O. In Natural Products for Pest Management; ACS Symposium Series, Vol. 927; Rimando, A. M., Duke, S. O., Eds.; American Chemical Society: Washington, DC, 2006; pp 2-21.

(8) Duke, S. O.; Dayan, F. E.; Romagni, J. G.; Rimando, A. M. Natural products as sources of herbicides: current status and future trends. Weed Res. 2000, 40, 99-111.

(9) Macías, F. A.; Galindo, J. L. G.; Galindo, J. C. G. Evolution and current status of ecological Phytochemistry. Phytochemistry 2007, 68, 2917-2936.

(10) Proceedings of the First World Congress on Allelopathy. A science of the future, Cádiz, Spain, September 16-20, 1996.

(11) Jingwen, B.; Jing, W.; Bo, T.; Chunhong, T. Allelopathy and preliminary separation of allelopathic substance in the extracts of wheat seed germination. Adv. Mater. Res. 2012, 468, 565-568.

(12) Pérez de Luque, A.; Galindo, J. C. G.; Macías, F. A.; Jorrín, J. Sunflower sesquiterpene lactone models induce Orobanche cumana seed germination. Phytochemistry 2000, 53, 45-50.

(13) Razzaq, A.; Cheema, Z. A.; Jabran, K.; Hussain, M.; Farooq, M.; Zafar, M. Reduced herbicide doses used together with allelopathic sorghum and sunflower water extracts for weed control in wheat. $J$. Plant Prot. Res. 2012, 52 (2), 281-285.

(14) Dhima, K.; Vasilakoglou, I.; Lithourgidis, A.; Mecolari, E.; Keco, R.; Agolli, X.; Eleftherohorinos, I. Phytotoxicity of 10 winter barley varieties and their competitive ability against common poppy and ivyleaved speedwell. Exp. Agric. 2008, 44 (3), 385-397.

(15) Lynn, M. D. News from Online-Plants and Photosynthesis. J. Chem. Educ. 2010, 87 (2), 130-132.

(16) Agosta, C. W. Medicines and Drugs from Plants. J. Chem. Educ. 1997, 74 (7), 857.

(17) Macías, F. A.; Galindo, J. L. G.; Galindo, J. C. G. Evolution and current status of ecological phytochemistry. Phytochemistry 2007, 68, 2917-2936.

(18) Fundación española para la ciencia y la tecnología (FECYT Home Page). http://www.campuscientificos.es (accessed November 2013).

(19) Cadiz Allelopathy Group Home Page. http://www.uca.es/ grupos-inv/FQM286 (accessed November 2013).

(20) Chang-Hung, C. Allelopathy and sustainable agriculture. In Allelopathy; ACS Symposium Series, Vol. 582; Inderjit, Dakshini, K. M. M., Einhellig, F. A., Eds; American Chemical Society: Washington, DC, 1994; pp 211-223.

(21) Sanders, H. J. An expanding array of chemicals is the most powerful weapon in the relentless war against weeds. Chem. Eng. News 1981, 59 (31), 20-36.

(22) Powell, R. G. Plant Seeds as Sources of Potential Industrial Chemicals, Pharmaceuticals, and Pest Control Agents. J. Nat. Prod. 2009, 72 (3), 516-523.

(23) Tanaka, J. A topical approach to organic chemistry for agricultural students. J. Chem. Educ. 1960, 37 (1), 33-34.

(24) Cutler, H. G. A fresh look at the wheat coleoptile bioassay. In Proceedings of the 11th Annual Meeting of the Plant Growth Regulator Society of America, Boston, MA, July 29-August 1, 1984.

(25) The length of the second experiment was beyond the duration of the workshop for each group of participants, and the long-term monitoring was therefore carried out through social networks. A recompilation of all results was sent to all students by e-mail for the purpose of comparing their results with the others groups and drawing conclusions from their experience.

(26) Macías, F. A.; Marin, D.; Oliveros-Bastidas, A.; Castellano, D.; Simonet, A. M.; Molinillo, J. M. G. Structure-activity relationships (SAR) studies of benzoxazinones, their degradation products and analogues. Phytotoxicity on standard target species (STS). J. Agric. Food Chem. 2005, 53 (3), 538-548.

(27) Soderquist, C. J. Juglone and allelopathy. J. Chem. Educ. 1973, 50 (11), 782-783.
(28) Thakur, A. Juglone: a therapeutic phytochemical from Juglans regia L. J. Med. Plants Res. 2011, 5 (22), 5324-5330.

(29) Zimmermann, S.; Kaiser, M.; Brun, R.; Hamburger, M.; Adams, M. Cynaropicrin: the first plant natural product with in vivo activity against Trypanosoma brucei. Planta Med. 2012, 78, 553-556.

(30) Gonzalez, A. G.; Darias, V.; Alonso, G.; Boada, J. N.; Feria, M. Cytostatic activity of sesquiterpene lactones from Compositae of the Canary Islands. Planta Med. 1978, 33, 356-359.

(31) Kumar, T.; Larokar, Y. K.; Iyer, S. K.; Kumar, A.; Tripathi, D. K. Phytochemistry and Pharmacological Activities of Silybum marianum: a review. Int. J. Pharm. Phytopharmacol. Res. 2011, 1 (3), 124-133.

(32) Khan, R.; Khan, M. A.; Wagas, M.; Haroon, M.; Hussain, Z.; Khan, N.; Ullah, I.; Ramzan, M.; Bashir, S. Bioherbicidal activity of some winter weeds against some crops. Pak. J. Weed Sci. Res. 2012, 18 (4), 561-569.

(33) Shimizu, S.; Ishihara, N.; Umehara, K.; Miyase, T.; Ueno, A. Sesquiterpene glycosides and saponins from Cynara cardunculus L. Chem. Pharm. Bull. 1987, 36 (7), 2466-2474.

(34) Pieri, V.; Stuppner, H. Quantification of cynaropicrin in Artichoke leaf extracts by ${ }^{1} \mathrm{H}$ NMR spectroscopy. Planta Med. 2011, 77, 1756-1758.

(35) Kapiszewska, M.; Soltys, E.; Visioli, F.; Cierniak, A.; Zajac, G. The protective ability of the Mediterranean plant extracts against the oxidative DNA damage. The role of the radical oxygen species and the polyphenol content. J. Physiol. Pharmacol. 2005, 56, 183-197.

(36) Cardoso, N. C.; Vieira, V. C. C.; Cazarin, C. B.; Agellon, S.; Weiler, H.; Marostica, M. R. Effects of the fructooligosaccharides (FOS) and inulin on bone metabolism of the skeletally mature female rats. Aliment. Nutr. 2012, 23, 515-520.

(37) Tyumkina, T.; Nuriev, I.; Khalilov, L.; Akhmetova, V.; Dzhemilev, U. PMR and 13C NMR spectra of biologically active compounds. XIII. Structure and stereochemistry of a new phenylpropanoid glycoside isolated from Onopordum acanthium seeds. Chem. Nat. Compd. 2009, 45, 61-65.

(38) Martín, A. A.; Luna del Castillo, J. D. Bioestadistica para las Ciencias de la Salud, 3rd ed.; Norma: Madrid, Spain, 1990.

(39) Koul, O.; Walia, S. Comparing impacts of plant extracts and pure allelochemicals and implications for pest control. $C A B$ Rev. 2009, $4,1-30$.

(40) Macías, F. A.; Molinillo, J. M. G.; Galindo, J. C. G.; Varela, R. M.; Simonet, A. M.; Castellano, D. The use of allelopathic studies in the search for natural herbicides. J. Crop Prod. 2001, 4, 237-255.

(41) Dayan, F.; Romagni, J.; Tellez, M.; Rimando, A.; Duke, S. Managing weeds with natural products. Pestic. Outlook 1999, 10, 185188. 